\title{
Intravenous Immunoglobulin Therapy in COVID-19 Disease
}

COVID-19 Hastalı̆̆ında İntravenöz İmmunoglobulin Tedavisi

\author{
Elif Şeker ${ }^{1}$, Öner Özdemir ${ }^{2}$, Ayşegül Pala ${ }^{1}$
}

${ }^{1}$ Sakarya University, Training and Research Hospital, Department of Pediatrics, Sakarya, Turkey

2 Sakarya University, Training and Research Hospital, Department of Pediatrics, Division of Allergy and Immunology, Sakarya, Turkey

Yazışma Adresi / Correspondence:

\section{Öner Özdemir}

Sakarya University, Training and Research Hospital, Department of Pediatrics, Division of Allergy and Immunology, 54100, Sakarya, Turkey

T: +90 (264) $4445400 \quad$ E-mail: ozdemir_oner@hotmail.com

Geliş Tarihi / Received : 25.09.2020 Kabul Tarihi / Accepted : 09.03.2021

Orcid:

Öner Özdemir https://orcid.org/0000-0002-5338-9561

Ayşegül Pala https://orcid.org/0000-0001-9056-144X

Elif Şeker https://orcid.org/0000-0002-2975-6616

( Sakarya Tip Dergisi / Sakarya Med J 2021, 11(2):470-472 ) DOI: 10.31832 smj.799820 


\section{Dear Editor}

High dose IVIG has been an appropriate immunomodulatory treatment option for prophylaxis of severe infections in autoimmune and inflammatory diseases. ${ }^{1}$

It is suggested that the plasma levels of pro-inflammatory cytokines are higher in COVID-19 patients with severe clinical course and there is a cytokine storm related to the severity of the disease. Therefore, IVIG is presented as a treatment option in severe COVID-19 patients. $^{2,3}$

Mechanisms suggesting the benefit of IVIG in SARSCoV2 therapy can be counted as; neutralizing antibodies binding to the ACE2 receptor to prevent viral entry into the cell, blocking receptors associated with the target cell and preventing pathogens from damaging the cell.,4

In addition, IVIG has IgG dimers that inhibit FcR activation on natural immune effector cells. This prevents antibody-dependent enhancement (ADE), a paradoxical condition that allows the pathogen to enter the cell. ${ }^{5,6}$

It has also been observed to improve coagulation abnormalities in septic patients that deteriorate due to inflammatory events in the pathogenesis of COVID-19.

In previous studies of SARS and MERS, the benefit of IVIG treatment has been demonstrated. ${ }^{8}$

Wang et al. reported that 40 patients with SARS were given IVIG, 22 of whom had severe cytopenia, and a significant improvement in leukocyte and platelet counts was noted after IVIG. ${ }^{9}$

In a case series reported by Cao et al., IVIG was given 0.3$0.5 \mathrm{~g}$ per $\mathrm{kg}$ weight per day for five days to 3 patients with severe COVID-19 pneumonia diagnosed by CT scan. It was reported that patients showed a rapid recovery 2 days after IVIG treatment and their CT scan findings were improved. In addition, no side effects were reported in any of the 3 patients. ${ }^{10}$

Lanza et al. reported an increased need for oxygen in 42 -year-old woman diagnosed with COVID-19 on the 6th day and bilateral infiltration and consolidation worsened in the CT findings, and the radiological findings and blood values were rapidly improved after 4 days of high-dose IVIG treatment. ${ }^{3}$

IVIG can interrupt the storm of inflammatory factors at an early stage, enhance immune function. Ling and colleagues recommended early initiation of IVIG treatment for severe and critical type COVID-19 patients. $^{11}$

In summary, early use of IVIG therapy in selected cases for COVID-19 pneumonia has been reported to shorten hospital stay, reduce the need for mechanical ventilation, and benefit patients' early recovery. More controlled studies are needed to demonstrate therapeutic benefits of this IVIG therapy. 
Sakarya Med J 2021;11(2):470-472

SEKER et al., IVIG Therapy in COVID-19 Disease

\section{References}

1. Galeotti C, Kaveri SV, Bayry J. IVIG-mediated effector functions in autoimmune and inflammatory diseases. Int Immunol. 2017;29(11):491-498. doi:10.1093/intimm/dxx039.

2. Díez JM, Romero C, Gajardo R. Currently available intravenous immunoglobulin contains antibodies reacting against severe acute respiratory syndrome coronavirus 2 antigens. Immunotherapy. 2020;12(8):571-576. doi:10.2217/imt-2020-0095.

3. Lanza M, Polistina GE, Imitazione $P$, et al. Successful intravenous immunoglobulin treatment in severe COVID-19 pneumonia. IDCases. 2020;21:e00794. Published 2020 May 16. doi:10.1016/j.idcr.2020.e00794.

4. Wu C, Chen X, Cai Y, et al. Risk Factors Associated With Acute Respiratory Distress Syndrome and Death in Patients With Coronavirus Disease 2019 Pneumonia in Wuhan, China. JAMA Intern Med. 2020;180(7):934-943. doi:10.1001/jamainternmed.2020.0994.

5. Kulkarni R. Antibody-Dependent Enhancement of Viral Infections. Dynamics of Immune Activation in Viral Diseases. 2019;9-41. Published 2019 Nov 5. doi:10.1007/978-981-151045-8_2.

6. Nguyen AA, Habiballah SB, Platt CD, Geha RS, Chou JS, McDonald DR. Immunoglobulins in the treatment of COVID-19 infection: Proceed with caution!. Clin Immunol. 2020;216:108459. doi:10.1016/j.clim.2020.108459.
7. Zheng C, Wang J, Guo H, et al. Risk-adapted Treatment Strategy For COVID-19 Patients. Int J Infect Dis. 2020;94:74-77. doi:10.1016/j.ijid.2020.03.047.

8. Arabi YM, Arifi AA, Balkhy HH, et al. Clinical course and outcomes of critically ill patients with Middle East respiratory syndrome coronavirus infection. Ann Intern Med. 2014;160(6):389-397. doi:10.7326/M13-2486.

9. Wang JT, Sheng WH, Fang CT, et al. Clinical manifestations, laboratory findings, and treatment outcomes of SARS patients. Emerg Infect Dis. 2004;10(5):818-824. doi:10.3201/ eid1005.030640.

10. Cao W, Liu X, Bai T, et al. High-Dose Intravenous Immunoglobulin as a Therapeutic Option for Deteriorating Patients With Coronavirus Disease 2019. Open Forum Infect Dis. 2020;7(3):ofaa102. Published 2020 Mar 21. doi:10.1093/ofid/ofaa102.

11. Lin $L, L u L, C a o$ W, Li T. Hypothesis for potential pathogenesis of SARS-CoV-2 infection-a review of immune changes in patients with viral pneumonia. Emerg Microbes Infect. 2020;9(1):727-732. doi:10.1080/22221751.2020.1746199. 